\title{
HILANGNYA BUDAYA “NGAJENI DALAN” KOMUNITAS JAWA DESA ALAS BULUH KABUPATEN BANYUWANGI
}

\author{
Tutut Eka Sri Wahyuni ${ }^{1}$, Ismaul Fitroh ${ }^{2}$ \\ Fakultas Keguruan dan Ilmu Pendidikan, Universitas PGRI Banyuwangi ${ }^{1}$ \\ Email : Tututade3@gmail.com, \\ Email : ismaulfitroh@gmail.com
}

\begin{abstract}
ABSTRAK
Ngajeni dalan adalah ritual komunitas Jawa di desa Alabulu, ngajeni dalan sendiri dalam bahasa jawa "ngaji" yang artinya mengaji dan "dalan" artinya jalan raya. Ritual ngajeni dalan adalah sejarah 10 tahun lalu, karena jalan di desa Alasbuluh masuk dalam jalan propinsi atau jalur utama, banyak sekali kejadian kecelakaan lalu lintas yang terjadi hampir setiap hari dan selalu memakan korban jiwa. Ngajeni dalan di lakukan agar para pengguna jalan raya selamat baik dalam perjalanan berangkat dan pulang juga selamat kembali sampai rumah. Ritual ngajeni dalan memiliki banyak makna bagi setiap individunya, dari kegiatan ritual yang sudah dilakukan percaya atau tidak banyak warga jawa khususnya, merasakan manfaat atau kebaikan yang didapat, namun semua kembali pada keyakinan dan kepercayaan masingmasing manusianya. Secara umum penelitian ini bertujuan : (1) Untuk mengetahui latar belakang terjadinya tradisi "ngajeni dalan", (2) Untuk mengetahui tata cara pelaksanaan kegiatan "ngajeni dalan” masyarakat jawa di desa Alasbulu, (3) Untuk memberi pengetahuan, wawasan dan khasanah dari ritual tradisi gajeni dalan sejak masa lampau untuk masyarakat luas pada umumnya serta untuk masyarakat yang tinggal di wilayah Desa Alasbulu Kecamatan Wongsorejo khususnya. Jenis peneltian kualitatif dan pengumpulan data menggunakan teknik snow ball. Dan hasil skripsi ini mengetahui bahwa sejarah ritual ngajeni dalan berasal dari suku jawa pendatang dan kegiatan ritual hanya dilakukan oleh warga asli keturunan jawa.
\end{abstract}

\section{Kata kunci : Pergeseran Budaya, Ngajeni Dalan, Ritual, Komunitas Jawa.}

\begin{abstract}
Ngajeni dalan is a ritual Javanese community in the village of Alabulu, ngajeni dalan itself in the language of Java "ngaji" which means mengaji and "dalan" means the highway. The ngajeni ritual is a history 10 years ago, because the road in the village of Alasbuluh entered the provincial or main road, there were many traffic accidents that happened almost every day and always took casualties. Ngajeni dalan in doing so that the users of the highway survived both on the way to leave and go home also safely back home. Ritual ngajeni dalan has a lot of meaning for each individual, from ritual activities that have been done believe or not many Javanese in particular, feel the benefits or goodness gained, but all returned to the beliefs and beliefs of each human being. In general, this study aims: (1) To know the background of the tradition of "ngajeni dalan", (2) To know the procedures for the implementation of
\end{abstract}


"ngajeni dalan" activities in Java community in Alasbulu village, (3) To give knowledge, ritual gajeni tradition dalan since the past for the wider community in general and for the people who live in the village area Alasbulu Wongsorejo district in particular. This is a qualitative research and data collection using the snow ball technique. And the results of this thesis know that the history of rituals ngajeni dalan originated from tribal Javanese migrants and ritual activities are only done by indigenous Javanese descendants.

\section{Keywords : Cultural Shift, Ngajeni Dalan, Ritual, Community Of Java}

\section{PENDAHULUAN}

\subsection{Latar Belakang}

Banyuwangi adalah sebuah

Kabupaten di Provinsi Jawa Timur, terletak di ujung timur Pulau Jawa. Kabupaten Banyuwangi berbatasan dengan Kabupaten Situbondo di utara, Selat Bali di timur, Samudra Hindia di selatan serta Kabupaten Jember dan Kabupaten Bondowoso di barat. Pelabuhan Ketapang menghubungkan Pulau Jawa dengan Pelabuhan Gilimanuk di Bali. Banyuwangi adalah kabupaten terluas di Jawa Timur. Luasnya 5.782,50 $\mathrm{km}$. Wilayahnya cukup beragam, dari dataran rendah hingga pegunungan. Kawasan perbatasan dengan Kabupaten Bondowoso, terdapat rangkaian Dataran Tinggi Ijen dengan puncaknya Gunung Raung (3.282 m) dan Gunung Merapi (2.800 m), keduanya adalah gunung api aktif. Bagian selatan terdapat perkebunan, peninggalan sejak zaman Hindia Belanda. Di perbatasan dengan Kabupaten Jember bagian selatan, merupakan kawasan konservasi yang kini dilindungi dalam sebuah cagar alam, yakni Taman Nasional Meru Betiri. Pantai Sukamade merupakan kawasan pengembangan penyu. Di Semenanjung Blambangan juga terdapat cagar alam, yaitu Taman Nasional Alas Purwo (Badan Pusat Statistik kabupaten Banyuwangi, 2013).

Kabupaten Banyuwangi memiliki 25 kecamatan dan 189 desa, 28 kelurahan. Salah satu diantaranya adalah Kecamatan Wongsorejo, dimana Kecamatan Wongsorejo sendiri memiliki 12 desa, diantaranya Desa Bangsring, Desa Bengkak, Desa Alasbulu, Desa Alasrejo, Desa Sidodadi, Desa Sidowangi, Desa Sumberanyar, Desa Sumberkencono, Desa Watukebo, Desa Bimorejo, dan desa Wongsorejo sebagai Kecamatan. 
Diantara 12 Desa di Kecamatan Wongsorejo, Desa Alasbulu adalah desa yang sangat menarik untuk diteliti, hal ini dikarenakan Desa Alasbulu merupakan salah satu desa yang penduduk jawanya lebih banyak dibandingkan dengan penduduk madura yang mayoritas di Kecamatan Wongsorejo. Letak dan kondisi geografis Desa Alasbulu berada di daratan rendah dengan gestur tanah nya yang banyak mengandung air sehingga mudah untuk digunakan untuk bercocok tanam. Desa Alasbulu berada di Kecamatan Wongsorejo Kabupaten Banyuwangi dengan batasanbatasan wilayah sebagai berikut:

a. Sebelah Utara berbatasan dengan Desa Wongsorejo

b. Sebelah Selatan berbatasan dengan Desa Bengkak

c. Sebelah Timur berbatasan dengan Selat Bali yang menghubungkan antara Kabupaten Banyuwangi dengan Bali

d. Sebelah Barat berbatasan dengan Hutang Lindung milik perhutani (Sumber : Hasil Pengukuran SISMIOP Tahun 2004 Desa Alasbulu Kecamatan Wongsorejo Kabupaten Banyuwangi).

Mayoritas penduduk desa Alasbulu adalah pendatang dari Jawa Tengah dan daerah Jawa bagian Selatan biasanya disebut
"Wong Jowo Kidulan", yang mencakup daerah Genteng, Srono, Tegaldlimo, Wonosobo, namun kebanyakan pendatang yang dari daerah selatan adalah warga Genteng yang menikah dengan penduduk asli Wongsorejo warga Madura dan akhirnya memilih menetap di desa Alasbulu. Jadi, meskipun mayoritas keseluruh warga di Kecamatan Wongsorejo adalah Madura, namun di desa Alasbulu sendiri orang Jawa masih di bilang cukup banyak dan mayoritas.

Masyarakat Jawa di Desa Alasbulu masih menganut Islam Kejawen dalam melakukan berbagai aktivitas sehari-hari juga dipengaruhi oleh keyakinan, konsepkonsep, pandangan-pandangan, nilai-nilai budaya, dan norma-norma yang kebanyakan berada di alam pikirannya. Menyadari kenyataan seperti itu, maka orang Jawa terutama dari kelompok kejawen tidak suka memperdebatkan pendiriannya atau keyakinannya tentang Tuhan. Mereka tidak pernah menganggap bahwa kepercayaan dan keyakinan sendiri adalah yang paling benar dan yang lain salah. Sikap batin yang seperti inilah yang merupakan lahan subur untuk tumbuhnya toleransi yang amat besar baik di bidang kehidupan beragama maupun di 
bidang yang lain (Koentjaraningrat, 2008: $312)$.

Masyarakat jawa dikenal sebagai masyarakat yang sangat religious, religious dalam arti mengakui ada kekuatan/kekuasaan di luar manusia. Lebih tepatnya kekuasaan alam transenden atau supra natural. Dapat di ketahui bahwa masyarakat jawa di kenal mempunyai suatu tradisi dalam berbagai ritual yang merupakan sebuah gambaran atau wujud ekspresi yang di lakukan dalam kehidupan sehari-hari. Sebagian orang jawa boleh dikatakan masih percaya adanya setan atau hantu yang menggangu manusia. Itulah sebabnya pada saat melakukan perjalanan kemana pun hendaknya berhat-hati, apalagi melewati hutan yang dianggap wingit atau angker (Endraswara, 2018:9-10).

Ritual atau ritus dilakukan dengan tujuan untuk mendapatkan berkah atau rezeki yang banyak dari suatu pekerjaan. Seperti upacara menolak balak dan upacara karena perubahan atau siklus dalam kehidupan manusia seperti kelahiran, pernikahan dan kematian (Bustanuddin, 2007; 95) . Pada dasarnya ritual adalah rangkaian kata, tindakan pemeluk agama dengan menggunakan benda-benda, peralatan dan perlengkapan tertentu, DOI: $10.31227 /$ osf.io ditempat tertentu dan memakai pakaian tertentu pula (Suprayogo, 2001;41).

Ngajeni dalan adalah ritual komunitas Jawa di desa Alabulu, ngajeni dalan sendiri dalam bahasa jawa "ngaji" yang artinya mengaji dan "dalan" artinya jalan raya. Ritual ngajeni dalan adalah sejarah 10 tahun lalu, karena jalan di desa Alasbuluh masuk dalam jalan propinsi atau jalur utama, banyak sekali kejadian kecelakaan lalu lintas yang terjadi hampir setiap hari dan selalu memakan korban jiwa. Ngajeni dalan di lakukan agar para pengguna jalan raya selamat baik dalam perjalanan berangkat dan pulang juga selamat kembali sampai rumah.

Ritual ngajeni dalan sendiri hanya bisa ditemukan di Desa Alasbulu Kecamatan Wongsorejo yang hanya dilakukan oleh warga Jawa (turunan jowo) pendatang yang kebanyakan dari daerah Jawa Tengah dan daerah Jawa Banyuwangi bagian selatan, dimana Desa Alasbulu mayoritas adalah orang jawa meskipun berstatus pendatang namun penduduk jawa di Desa Alasbulu lebih dominan di bandingkan dengan desa lainnya yang berada di Kecamatan Wongsorejo.

Membahas tentang ritual, penduduk Jawa di Desa Alasbulu terkenal dengan 
ritual malam jumat legi yang sering dilakukan dalam setiap kegiatan di kehidupan sehari-harinya. Salah satunya adalah ritual ngajeni dalan, dimana pencetus kegiatan ritual tersebut adalah orang jawa pertama yang tinggal di Desa Alasbulu dan terus turun-temurun pada keluarganya yang kemudian di ikuti oleh warga jawa lainnya, dengan harapan dan doa yang sama agar terhindar dari bahaya saat berkendara di jalan raya.

Ritual ngajeni dalan memiliki banyak makna bagi setiap individunya, dari kegiatan ritual yang sudah dilakukan percaya atau tidak banyak warga jawa khususnya, merasakan manfaat atau kebaikan yang didapat, namun semua kembali pada keyakinan dan kepercayaan masing-masing manusianya.

Seiring berkembangnya jaman dan adanya akulturasi budaya, tradisi yang sudah menjadi budaya para sesepuh terdahulu perlahan menghilang dan sudah jarang ditemui kegiatan pelaksaannya. Salah satu budaya yang hilang adalah ritual " ngajeni dalan “.

Berdasarkan latar belakang diatas, maka penulis mengkaji tentang Pergeseran Budaya " Ritual Ngajeni Dalan " Komunitas Jawa Di Desa Alasbuluh DOI: $10.31227 /$ osf.io
Kabupaten Banyuwangi. Alasan yang menjadi dasar dalam penelitian tersebut adalah tempat yang strategis dan topik yang dikaji sangat menarik. Penelitian ini diharapkan sebagai upaya dalam mengkaji lebih dalam tentang penyebab hilangnya budaya ritual ngajeni dalan di desa Alasbulu Kecamatan Wongsorejo.

\subsection{Landasan Teori}

\subsubsection{Pengertian Desa Alasbulu}

Desa Alasbulu merupakan sebuah Desa yang terdapat di wilayah Kecamatan Wongsorejo Kabupaten Banyuwangi. Kata Alasbulu diambil dari bahasa jawa "alas" yang artinya hutan dan "bulu" yang berarti rambut/bulu. Menurut salah satu penduduk di desa tersebut dahulu yang pertama berkunjung mengatakan bahwa daerah tersebut merupakan sebuah hutan yang lebat dan baru terdapat 3-4 bangunan gubuk kecil. Konon yang pertama meninggali daerah hutan tersebut adalah warga bernama mbah Jumitun, beliau perantau dari Jawa Tengah, kemudian beliau menikah dengan warga daerah Genteng desa Pring Sejuta yang bernama mbah Tohir dan akhirnya memilih untuk tinggal di hutan tersebut. Namun dari kisah mbah Jumitun beberapa kisah lain juga muncul, diantaranya yang pertama kali menginjakkan kaki adalah seorang nelayan 
dari Sleman Jawa Tengah, dan hingga saat ini sejarah desa Alasbulu sendiri masih belum dipastikan kebenarannya, karena belum ada yang mencoba menggali tentang toponomi dan sejarah salah satu desa yang berada di Kecamatan Wongsorejo tersebut.

Mayoritas penduduk desa Alasbulu adalah pendatang dari Jawa Tengah dan daerah Jawa bagian Selatan biasanya disebut "Wong Jowo Kidulan", yang mencakup daerah Genteng, Srono, Tegaldlimo, Wonosobo, namun kebanyakan pendatang yang dari daerah selatan adalah warga Genteng yang menikah dengan penduduk asli Wongsorejo warga Madura dan akhirnya memilih menetap di desa Alasbulu. Jadi, meskipun mayoritas keseluruh warga di Kecamatan Wongsorejo adalah Madura, namun di desa Alasbulu sendiri orang Jawa masih di bilang cukup banyak dan mayoritas.

\subsubsection{Pengertian Ngajeni Dalan}

Ngajeni dalan adalah ritual penduduk Jawa di desa Alabulu, ngajeni dalan sendiri dalam bahasa jawa "ngaji" yang artinya mengaji dan "dalan" artinya jalan raya. Ritual ngajeni adalah sejarah 10 tahun lalu, karena jalan di desa Alasbuluh masuk dalam jalan propinsi atau jalur utama, banyak sekali kejadian kecelakaan lalu lintas yang DOI: $10.31227 /$ osf.io terjadi hampir setiap hari dan selalu memakan korban jiwa. Ngajeni dalan di lakukan agar para pengguna jalan raya selamat baik dalam perjalanan berangkat dan pulang juga selamat kembali sampai rumah. Ritual ngajeni dalan hanya di lakukan oleh penduduk jawa di desa Alabulu.

Ngajeni dalan yang dilakukan oleh penduduk jawa di Desa Alasbulu ini hanya dilakukan pada malam jumat manis saja, karena masyarakat jawa kuno percaya pada malam jumat manis roh-roh para leluhur datang untuk meminta doa kepada anak dan cucu mereka. Ritual ngajeni dalan sendiri hanya bisa ditemui di Desa Alasbulu, namun kegiatan ritual tidak di pertontonkan seraca umum. Ritual ngajeni dalan dilakukan oleh perseorangan yang pada malam jumat legi memang menyiapkan sesajen untuk di letakkan di pinggir jalan atau gang-gang kecil menuju perumahan

\subsubsection{Pengertian Jalan Raya}

Menurut Undang-undang No.38/2004 jalan pengertian jalan adalah prasarana transportasi darat yang meliputi segala bagian jalan, termasuk bangunan pelengkap dan perlengkapannya yang diperuntukkan bagi lalu lintas, yang ada di atas dipermukaan tanah, di bawah 
permukaan tanah dan/atau air, serta di atas permukaan air, kecuali jalan kereta api, jalan lori, dan jalan kabel. Prasarana transportasi darat yang meliputi segala bagian jalan, termasuk bangunan pelengkap dan perlengkapannya yang diperuntukkan bagi lalu lintas, yang ada di atas dipermukaan tanah, di bawah permukaan tanah dan/atau air, serta di atas permukaan air, kecuali jalan kereta api, jalan lori, dan jalan kabel (Wilkimedia. Jalan Arteri.com).

Berdasarkan kedua pendapat tentang pengertian jalan raya, dapat ditarik kesimpulan bahwa Jalan raya adalah jalan utama yang menghubungkan satu kawasan dengan kawasan yang lain. Biasanya jalan besar ini digunakan untuk kendaraan bermotor, digunakan oleh masyarakat umum. Alasan peneliti melakukan penelitian yang berhubungan dengan jalan raya adalah karena kegiatan ritual ngajeni dalan ini hanya dilakukan oleh penduduk jawa di Desa Alasbulu yang tujuannya agar pengguna jalan raya selamat dari kecelakaan maut dan bahaya lalu lintas lainnya.

\subsubsection{Tradisi}

\subsubsection{Pengertian Tradisi}

Tradisi adalah kebiasaan yang turun temurun dalam suatu masyarakat. Tradisi DOI: $10.31227 /$ osf.io merupakan mekanisme yang dapat membantu untuk memperlancar perkembangan pribadi anggota masyarakat, misalnya dalam membimbing anak menuju kedewasaan. Tradisi juga penting sebagai pembimbing pergaulan bersama di dalam masyarakat. W.S. Rendra menekankan pentingnya tradisi dengan mengatakan bahwa tanpa tradisi, pergaulan bersama akan menjadi kacau, dan hidup manusia akan menjadi biadab. Namun demikian, jika tradisi mulai bersifat absolut, nilainya sebagai pembimbing akan merosot. Jika tradisi mulai absolut bukan lagi sebagai pembimbing, melainkan merupakan penghalang kemajuan. Oleh karena itu, tradisi yang kita terima perlu kita renungkan kembali dan kita sesuaikan dengan zamannya (Johanes, 1998:12-13).

Tradisi (Bahasa Latin: traditio, "diteruskan") atau kebiasaan, dalam pengertian yang paling sederhana adalah sesuatu yang telah dilakukan untuk sejak lama dan menjadi bagian dari kehidupan suatu kelompok masyarakat, biasanya dari suatu negara, kebudayaan, waktu, atau agama yang sama. Hal yang paling mendasar dari tradisi adalah adanya informasi yang diteruskan dari generasi ke generasi baik tertulis maupun (sering kali) 
lisan, karena tanpa adanya ini, suatu tradisi dapat punah. Pendapat lain dikemukakan oleh Koentjaraningrat (2008:103) yang mengatakan bahwa tradisi merupakan keyakinan yang dikenal dengan istilah animisme dan dinanisme. Animisme berarti percaya kepada roh-roh halus atau roh leluhur yang ritualnya terekspresikan dalam persembahan tertentu di tempat-tempat yang dianggap keramat.

Adapun pendapat lainnya dalam jurnal penelitian yang serupa, seperti yang dikemukakan oleh Amin (2000:6) yang mengatakan bahwa tradisi adalah kepercayaan agama mereka yang pertama, semua yang bergerak dianggap hidup dan mempunyai kekuatan gaib atau memiliki roh yang berwatak buruk maupun baik. Dengan kepercayaan tersebut mereka beranggapan bahwa disamping semua roh yang ada, terdapat roh yang paling berkuasa dan lebih kuat dari manusia. Dan, agar terhindar dari roh tersebut mereka menyembahnya dengan jalan upacara yang disertai dengan sesajisesaji.

Berdasarkan beberapa pendapat tentang tradisi di atas dapat di tarik kesimpulan, tradisi dalah sesuatu yang telah dilakukan sejak lama dan menjadi bagian dari kehidupan suatu kelompok masyarakat, biasanya dari suatu negara, kebudayaan, waktu, atau agama yang sama. Hal yang paling mendasar dari tradisi adalah adanya informasi yang diteruskan dari generasi ke generasi baik tertulis maupun (sering kali) lisan, karena tanpa adanya ini, suatu tradisi dapat punah.

\subsubsection{Macam-macam Tradisi}

a. Tradisi Selametan Suran Purworejo

Tradisi selametan suran (Siti Nurfaridah, 2014:57) merupakan sebuah tradisi yang ada di Desa Sutogaten yang dilaksanakan di halaman pesarean Mbah Damarwulan. Tradisi selametan suran dilakukan secara turun-temurun oleh warga masyarakat dengan ketentuan tidak lepas dari budaya Islam yakni sebagai rasa syukur kepada Allah Swt (Subhanahu wata'ala).

b. Tradisi Selametan Weton

Menurut Kamus Besar Bahasa Indonesia, Weton adalah hari lahir seseorang dengan pasarannya (Legi, Paing, Pon, Wage, Kliwon). Weton berasal dari kata wetu yang berarti lahir atau keluar yang mendapat akhiran "an" sehingga berubah menjadi kata benda. Selain itu weton dapat diartikan sebagai gabungan antara hari dan pasaran saat bayi dilahirkan ke dunia. Misalnya Senin Pon, Rabu Wage, Jumat Legi atau lainnya (Hari Setiawan, 2015:5). 


\section{c. Tradisi Slametan Jumat Legi}

Salah satu tradisi lokal yang masih dilakukan dan dipertahankan pada masyarakat perdesaan adalah "slametan jumat legi". Tradisi slametan jumat legi merupakan tradisi yang dilakukan oleh warga secara rutin sebulan sekali sesuai dengan penanggalan jawa, yakni setiap malam Jumat Legi (Zulkarnain, 2013:114). Malam Jumat Legi bagi masyarakat Jawa Timur dianggap sebagai malam keramat. Kegiatan Slametan Jumat Legi dilaksanakan di salah satu rumah warga secara bergantian, dan setiap warga membawa nasi berkat untuk dimakan bersama seusai membaca doa bersama. Setelah itu dilanjutkan dengan sosialisasi dan interaksi komunikasi antar sesama warga dan pengurus kelompok.

Berdasarkan ketiga penjelasan tentang tradisi diatas, peneliti menyimpulkan bahwa pada dasarnya setiap tradisi memiliki makna dan tujuan yang hampir sama yakni meminta berkah, menunjukkan rasa syukur kepada sang pencipta dengan cara yang berbeda pada setiap pelaksanaanya.

\subsubsection{Ritual}

\subsubsection{Pengertian Ritual}

Upacara ritual ini merupakan sistem keyakinan, dan gagasan tentang Tuhan,
Dewa-Dewa, Roh-roh halus, Neraka, Surga dan sebagainya, diwujudkan dalam bentuk upacara-upacara, baik yang bersifat musiman maupun yang kadangkala. (Koentjaraningrat, 2002). yang ditandai oleh sifat khusus yang menimbulkan rasa hormat dan pengalaman suci. (Rostiyati, ANI. 1997). Upacara ritual kehamilan (seperti 3 bulanan atau 7 bulanan), tidak diajarkan dalam Islam. Bagi kaum putih penganut Islam murni mereka menyebutnya dengan mengada-ada sesuatu yang awalnya tidak ada, dan itu termasuk bid'ah yang membawa kesesatan. Mereka mendasarkan sabda Rasulullah saw: Jauhilah semua perkara baru (dalam agama), karena semua perkara baru (dalam agama) adalah bid'ah, dan semua bid'ah merupakan kesesatan (Sunan Abu Dawud, no. 4607; Tirmidzi, 2676).

Upacara ritual biasanya dilakukan secara rutin oleh sekelompok masyarakat yang diatur dengan hukum masyarakat yang berlaku, (Koentjaraningrat, Ibid) dan melibatkan para warga dalam mencapai tujuan keselamatan bersama sebagai upaya manusia untuk mencari keselamatan, ketentraman, dan sekaligus menjaga kelestarian kosmos (Geertz, 1999), terhindar dari gangguan makhluk halus. 


\section{Clifford Geertz mengkategorikan} upacara ritual bagi masyarakat Jawa ke dalam empat jenis utama yaitu: Pertama, yang berkaitan dengan kehidupan: kelahiran, khitanan, pernikahan, dan kematian. Kedua, yang terkait dengan peristiwa perayaan Islam, misalnya Maulid Nabi. Ketiga, Bersih desa ("pembersihan desa"), berkaitan dengan integrasi sosial desa. Keempat, kejadian yang tidak biasa misalnya berangkat untuk perjalanan panjang, pindah rumah, mengubah nama, kesembuhan penyakit, kesembuhan akan pengaruh sihir, terhindar dari marabahaya, dan sebagainya.

Berdasarkan beberapa pendapat tentang ritual di atas dapat di tarik kesimpulan, bahwa pada dasarnya ritual adalah suatu upacara yang dilakukan secara turun-temurun yang berlau di suatu daerah. Dengan demikian, setiap memiliki uapacara ritual yang menjadi adat sendiri-sendiri, seperti ritual dalam pernikahan, ritual 7 bulanan, ritual kematian, dan ritual adat yang dilakukan di daerah-daerah tersebut, sebenarnya juga tidak lepas dari unsur sejarah.

\subsubsection{Macam-macam Ritual}

a. Ritual Adat Kasada, Suku Tengger

Bagi masyarakat Suku Tengger, Upacara adat adalah salah satu wujud rasa DOI: $10.31227 /$ osf.io syukur masyarakat Tengger kepada tuhan. Ada banyak upacara adat di masyarakat Tengger yang memiliki tujuan bermacammacam diantaranya meminta berkah, menjauhkan malapetaka, wujud syukur atas karunia yang diberikan tuhan kepada masyarakat Tengger.

b. Ritual Selametan di Pesarean Gunung Kawi

Ritual selametan yang dilaksanakan di Gunung Kawi tidak hanya dilaksanakan oleh orang Jawa, bahkan oleh seluruh penduduk Indonesia (Nuryani, 2010: 3-4). Pelaku ritual memiliki latar belakang suku, agama, bahasa, dan budaya yang berbeda. Tujuan pelaksanaan juga terlihat memiliki perbedaan dengan selametan yang dilaksanakan oleh masyarakat Jawa khususnya di desa-desa.

Dalam pelaksanaan ritual selametan di Gunung Kawi, mereka yang melaksanakan ritual selametan mengajukan berbagai permohonan kepada Tuhan melalui dua tokoh yang dimakamkan di tempat tersebut. Harapan tersebut ditulis dalam sebuah kertas yang diserahkan kepada modin beserta bunga dan kemenyan untuk selanjutnya dibacakan atau disampaikan pada saat ritual selametan.

c. Ritual Tedhak Siten 
Upacara tedhak siten diadakan karena adanya kepercayaan sementara orang bahwa tanah mempunyai kekuatan gaib, disamping itu adanya kepercayaan bahwa tanah dijaga oleh Bethara Kala. Oleh karena itu si anak perlu dikenalkan kepada Bathara Kala sipenjaga tanah, melalui upacara yang disebut tedhak siten, agar Bathara Kala tidak marah. Sebab apabila Bathara Kala marah, akan menimbulkan suatu bencana bagi sianak itu.

Dari beberapa penelitian ritual di atas, peneliti menyimpulkan bahwa ritual yang dilakukan di berbagai daerah tersebut memiliki tujuan yang sama yaitu agar terhindar dari bahaya (tolak-bala), dan masih percaya dengan adanya roh-roh halus. Ritual di atas juga memiliki kesamaan dengan kegiatan ritual yang sedang peneliti lakukan yaitu ritual ngajeni dalan yang tujuan pelaksaannya di jauhkan dari bahaya.

\subsubsection{Manfaat Ritual}

a. Ritual Adat Kasada, Suku Tengger

Upacara Ritual Kasada membawa banyak manfaat bagi masyarakat suku Tengger itu sendiri. Selain sebagai ajang meminta keselamatan, Upacara Kasada juga mampu menyedot atensi wisatawan untuk datang menyaksikannya. Disisi lain manfaat dari kegiatan ritual kasada adalah dapat DOI: $10.31227 /$ osf.io berkumpulnya kekeluargaan yang lebih akrab karena dalam upacara Kasada, masyarakat Suku Tengger berkumpul dengan membawa hasil bumi dan peternakan yang ditata di tempat bernama ongkek. Mereka berbondong-bondong membawa sesajen ini ke kawah Gunung Bromo untuk kemudian dilemparkan ke dalamnya.

b. Ritual Selametan di Pesarean Gunung Kawi

Ritual pesarean gunung kawi adalah budaya peninggalan leluhur yang wajib dilestarikan, karena mempunyai tujuan mulia bagi masyarakat sekitar Kawi, meski jaman sudah modern, mendekatkan diri kepada yang kuasa adalah penting. Apalagi mendoakan bagi leluhur kawasan hunung kawi, supaya mendapat berkah dan perlindungan daro Tuhan Yang Maha Esa, serta dijauhkan dari sifat perilau jahat. Selain itu acara ritual pesarean gunung kawi juga menarik perhatian bagi wisatawan asing maupun local yang dapat menaikkan potensi pariwisata bagi kawasan sekitar Kawi.

\section{c. Ritual Tedhak Siten}

Tedak siten merupakan ritual turun tanah untuk bayi berumur 8-11 bulan. Tidak hanya sekadar melestarikan tradisi, tedak 
siten memiliki nilai-nilai yang dapat diambil hikmahnya. Misalnya saja dari rangkaian dan uba rampai 'piranti' yang digunakan saat prosesi acara. Berbagai harapan dipanjatkan dari serangkaian upacara yang dilakukan. Misalnya harapan agar anak dapat menghadapi suka duka kehidupan, bersikap hati-hati, dan berani mengambil keputusan.

Dari ketiga manfaat ritual yang sudah dijelaskan diatas, maka peneliti dapat menyimpulkan bahwa dari keseluruhan kegiatan ritual memiliki kesamaan manfaat yaitu mempererat tali kekeluargaan antar sesama, melestarikan budaya leluhur, mengenalkan budaya asli jawa kepada anak cucu dan khalayak umum. Dari manfaat kegiatan ritual diatas juga memiliki perbedaan dengan kegiatan ritual yang sedang di teliti oleh peneliti saat ini yaitu ritual ngajeni dalan, dimana ritual ngajeni dalan tidak dipertontonkan kepada umum, melainkan ritual kegiatan individual, yang berbeda dengan ritual diatas yang juga berttujuan memikat para wisatawan dan ritual juga di laksanakan secara besarbesaran.

\subsubsection{Pengertian Budaya}

Budaya atau kebudayaan berasal dari bahasa Sansekerta yaitu buddhayah, yang DOI: $10.31227 /$ osf.io merupakan bentuk jamak dari buddhi (budi atau akal) diartikan sebagai hal-hal yang berkaitan dengan budi dan akal manusia. Dalam bahasa Inggris, kebudayaan disebut culture, yang berasal dari kata Latin Colere, yaitu mengolah atau mengerjakan. Bisa diartikan juga sebagai mengolah tanah atau bertani. Kata culture juga kadang diterjemahkan sebagai "kultur" dalam bahasa Indonesia.

Menurut Koentjaraningrat (dalam Muhammad Tawab, 2014:16) Kebudayaan adalah seluruh total dari pikiran, karya dan hasil karya yang dicetuskan oleh manusia sesudah suatu proses belajar. Oleh karena itu tanpa proses belajar, kita tidak mungkin mengerti maksud dan tujuan kebudayaan generasi sebelumnya. Itulah mengapa kita sebagai generasi muda harus semangat untuk belajar apalagi mengenai budaya, agar kita mengerti maksud dan tujuan dari kebudayaan yang diwariskan oleh nenek moyang kita.

Kebudayaan sangat erat hubungannya dengan masyarakat, beberapa definisi tentang budaya yang dikemukakan oleh beberapa ahli yaitu menurut

- Melville J. Herskovits dan Bronislaw Malinowski mengemukakan bahwa segala sesuatu yang terdapat dalam masyarakat 
ditentukan oleh kebudayaan yang dimiliki oleh masyarakat itu sendiri. Istilah untuk pendapat itu adalah Cultural-Determinism.

- Andreas Eppink, kebudayaan mengandung keseluruhan pengertian, nilai, norma, ilmu pengetahuan serta keseluruhan struktur-struktur sosial.

Dari beberapa pengertian di atas, maka peneliti menyimpulkan bahwa budaya adalah adalah merupakan cara hidup yang dipakai oleh sekelompok penduduk/masyarakat yang telah diturunkan secara turun temurun dari generasi sebelumnya kepada generasi berikutnya.

\subsubsection{Media Dalam Ritual Ngajeni Dalan}

\subsubsection{Pengertian Sesajen/Sandingan}

Sesaji/sandingan merupakan sajian, hidangan berupa makanan dan peralatan lain atau yang disebut juga ubarambe, digunakan untuk keperluan ritual selametan tersebut. Dari temuan di lapangan menunjukkan bahwa sesaji digunakan sebagai bentuk/media untuk berkomunikasi dengan Tuhan dan zat-zat gaib lain yang diyakini oleh masyarakat Islam Jawa melalui ritual selamatan.

Secara turun menurun orang Jawa sangat lekat dengan kepercayaan bahwa setiap orang memeliki empat saudara "goib" yang berada di empat penjuru mata angin atau biasa disebut dengan "Sedulur papat lima pancer". Sedulur yang ada di sisi timur disebut Tirtanata, sedulur yang ada di sisi utara disebut Warudijaya, sedulur yang ada di sisi selatan disebut Purbangkara dan sedulur yang ada di sisi barat disebut Sinotobatara. Sedang sesuatu yang disebut dengan Pancer adalah dirinya sendiri atau hati nurani setiap orang. Sedulur papat ini memiliki kemampuan dan mengendalikan hati nurani masing-masing orang. Dengan demikian secara turun temurun diyakini apabila orang ingin selalu dijaga, diingatkan atau dikendalikan dari keinginan dan pengaruh jahat, maka orang tersebut wajib 'menyapa'keempat sedulur yang ada di masing-masing arah penjuru mata angin itu. cara tegur sapa tersebut menurut kepercayaan yang diwariskan nenek moyang dilakukan dengan mengadakan sesaji Sega Putih, Sega Cemeng, Sega Abang dan Sega Kuning (Wahyana,2010: 27-28).

Dari pengertian di atas, maka dapat di simpulkan bahwa Sesajen/Sandingan berarti sajian atau hidangan berupa makanan atau bunga-bungaan dan sebagainya yang disajikan kepada orang (Makhluk) halus atau roh. Sesajen memiliki nilai sakral di 
sebagian besar masyarakat kita pada umumnya.

\subsubsection{Pengertian Jumat Manis/Jumat Legi}

Ritual malam jumat legi merupakan kegiatan/ritual keagamaan yang dimaknai warga NU sebagai objek sosial. Pemaknaan itu didapat lewat interaksi yang dilakukan oleh sesama warga NU. Oleh sebab menjadi objek sosial yang dimaknai, tentu menghasilkan presepsi yang berbeda. Perbedaan ini masuk dalam tataran mendukung pelaksanaannya ataukah justru menolaknya. Sebab masih ada anggapan pemaknaan bahwa ritual tersebut tidak ada dalam muatan hukum islam, alangkah tetapi hasil adopsi budaya jawa yang dikembangkan dengan symbol-simbol agama islam.

Ritual malam jumat legi erat kaitannya dengan akulturasi budaya hasil kepercayaan etnis jawa tempo dulu antara lain : animisme, dinamisme serta agama Hindu dan Budha dengan agama Islam. Agar diketahui secara lebih jelas tindakantindakan aktor yang melaksanakan ritual malam jumat legi digunakan teori fenomenologi untuk membedah maknamakna hasil dasar motif individu melakukan ritual. Diketahuinya tindakan-tindakan yang punya maksud dan tujuan tertentu digunakan teori interaksi simbolik sehingga munculnya tindakan subyek dapat diketahui secara medetail.

\subsubsection{Pengertian Jenang Abang- Jenang Putih}

Jenang yang dimaksud adalah dua buah nasi putih yang dibuat membentuk sebuah gundukan dan di taruh dalam sebuah piring dimana yang satu dibiarkan nasi putih polos dan yang satunya diberi tambahan gula merah diatasnya.

Pertama jenang pethak atau putih yang melambangkan seorang laki-laki, sementara jenang abrit atau merah yang melambangkan seorang perempuan. Dimana kedua jenang ini akan mengingatkan bahwa kita ada di dunia ini karena kedua orang tua kita.

\section{METODE PENELITIAN}

\subsection{Pendekatan Dan Jenis Penelitian}

Pendekatan masalah yang digunakan dalam penelitian ini adalah menggunakan pendekatan kualitatif. Pendekatan kualitatif adalah metode penelitian yang memusatkan perhatiannya pada prinsip-prinsip umum yang mendasar perwujudan satuan-satuan 
gejala yang ada dalam kehidupan sosial manusia. Penelitian kualitatif merupakan proses penelitian yang bertujuan memahami suatu masalah kemanusiaan yang didasarkan pada penyusunan suatu gambaran yang kompleks dan menyeluruh menurut pandangan yang rinci dari para informan serta dilaksanakan di tengah setting alamiah.

Basrowi dan Suwandi (2008:1) menyatakan bahwa penelitian kualitatif adalah salah satu prosedur penelitian yang menghasilkan data deskriptif berupa ucapan atau tulisan dan perilaku orang-orang yang diamati. Penelitian kualitatif adalah penelitian yang pemecahan masalahnya dilakukan dengan menggunakan data empiris.

Jenis penelitian yang digunakan dalam penelitian ini adalah jenis studi kasus. Studi kasus adalah suatu pendekatan untuk mempelajari, menerangkan, atau menginterpretasi suatu kasus dalam konteksnya secara natural tanpa adanya intervensi dari pihak luar. Jenis penelitian ini akan segera berlaku jika terdapat pertanyaan mengenai bagaimana (how) dan mengapa (why). Kecenderungan dalam studi kasus ini adalah bahwa studi ini berusaha untuk menyoroti suatu keputusan atau seperangkat keputusan, dan mengapa DOI: $10.31227 /$ osf.io keputusan tersebut diambil, bagaimana pelaksanaannya, dan apakah hasilnya.

Alasan digunakannya jenis penelitian studi kasus adalah karena metode penelitian yang digunakan merupakan metode penelitian deskriptif, dimana metode kualitatif ini dalam pelaksanaannya dapat dilakukan melalui studi kasus maupun studi komparasi. Berdasarkan hal tersebut, jenis penelitian studi kasus ini dipilih juga karena sifat kecenderungannya yang biasa memperhatikan permasalahan mengenai mengapa suatu kebijakan diambil dan bagaimana pelaksanannya.

\section{BAB IV LAPORAN PENELITIAN dan}

\section{ANALISIS DATA}

a. Laporan Hasil Penelitian

i. Sejarah Ritual Ngajeni Dalan

Ngajeni dalan adalah ritual penduduk Jawa di desa Alabulu, ngajeni dalan sendiri dalam bahasa jawa "ngaji" yang artinya mengaji dan "dalan" artinya jalan raya. Ritual ngajeni adalah sejarah 10 tahun lalu, karena jalan di desa Alasbuluh masuk dalam jalan propinsi atau jalur utama, banyak sekali kejadian kecelakaan lalu lintas yang terjadi hampir setiap hari dan selalu memakan korban jiwa. Ngajeni dalan di lakukan agar para pengguna jalan raya selamat baik dalam perjalanan berangkat 
dan pulang juga selamat kembali sampai rumah. Ritual ngajeni dalan hanya di lakukan oleh penduduk jawa di desa Alabulu.

Ritual ngajeni dalan memiliki banyak makna bagi setiap individunya, dari kegiatan ritual yang sudah dilakukan percaya atau tidak banyak warga jawa khususnya, merasakan manfaat atau kebaikan yang didapat, namun semua kembali pada keyakinan dan kepercayaan masing-masing manusianya.

Ngajeni dalan yang dilakukan oleh penduduk jawa di Desa Alasbulu ini hanya dilakukan pada malam jumat manis saja, karena masyarakat jawa kuno percaya pada malam jumat manis roh-roh para leluhur datang untuk meminta doa kepada anak dan cucu mereka. Ritual ngajeni dalan sendiri hanya bisa ditemui di Desa Alasbulu, namun kegiatan ritual tidak di pertontonkan seraca umum. Ritual ngajeni dalan dilakukan oleh perseorangan yang pada malam jumat legi memang menyiapkan sesajen untuk di letakkan di pinggir jalan atau gang-gang kecil menuju perumahan

$$
\begin{aligned}
& \text { ii. Pelaksanaan Kegiatan Ritual Ngajeni } \\
& \text { Dalan }
\end{aligned}
$$

Pelaksanaan kegiatan ritual ngajeni dalan komunitas jawa antara lain :
1. Setiap warga atau perseorangan menyiapkan sesajen antara lain, jenang bang, jenang putih, beberapa macam kembang (setiap pelaku ngajeni dalan berbeda), air mawar yang dicampur air putih bersih.

2. Kegiatan ritual dilakukan setiap malam jumat legi,

3. Setelah semua sesajen di siapkan dan di taruh disatu wadah (tampah),

4. Pelaku ngajeni dalan mengaji atau mendoakan sesajen setelah sholat magrib dan membaca Al-Qur'an dan membaca surat-surat sholawat Nabi.

5. Lalu pelaku ngajeni dalan berjalan menuju jalan raya dan meletakkan sesajen di pinggiran jalan raya tersebut.

Kegiatan ritual tersebut dilakukan oleh individu dan tidak dilakukan secara beramai-ramai, dan tidan dipertontonkan layaknya kegiatan ritual lain yang terkenal di Kabupaten Banyuwangi.

\section{DAFTAR RUJUKAN}

Badan Pusat Statistik kabupaten Banyuwangi, 2013

Darori Amin, Islam dan Kebudayaan Jawa (Yogyakarta, Gama Media, 2000), 6.). 
Bustanuddin Agus, Agama Dalam Kehidupan Manusia, (Jakarta: Raja Grafindo Persada, 2007),95

Geertz, 1999, Abangan, Santri, Priyayi, (Jakarta:Pustaka Jaya)

Hari Setiawan "Tradisi Slametan Weton" , Fakultas Seni Rupa Dan Desain Institut Seni Indonesia Surakarta 2015

Imam Suprayogo, Metodologi Penelitian Sosial-Agama, (Bandung: Remaja Rosda Karya, 2001), 41

Koentjaraningrat. (2008) . manusia dan kebudayaaan indonesia, 103-312. jakarta. Djambatan

Koentjaraningrat. 2002. Pengantar Ilmu Antropologi. PT. Rineka Cipta, Jakarta.

Koentjaraningrat,ibid, manusia dan kebudayaan indonesia, jakarta djambatan, cet. Ke-4,1999

Mardimin Johanes, Jangan Tangisi Tradisi (Yogyakarta: Kanisius, 1998), 12-13.

Muhammad Tawab, Pemikiran K.H. Muhammad Sholikhin Tentang Tradisi Selamatan, Yogyakarta: Universitas Islam Negeri Sunan Kalijaga, 2014

Moleong, Lexy J, Metodologi penelitian kualitatif, (BANDUNG:Remaja Rosdakarya, 2004)

Nuryani, "STRUKTUR WACANA RITUAL (Studi Kasus Ritual Selametan Di Pesarean Gunung Kawi, Malang, Jawa Timur) “.,Program Doktor Fakultas Ilmu Budaya UGM Yogyakarta 2013.

Rostiyati, ANI. 1997. Fungsi Upacara Tradisional Bagi Masyarakat Pendukungnya Masa Kini. Yogyakarta : Depdikbud.

Siti Nurfaridah, "Mitos Pesarean Mbah Damarwulan Dalam Tradisi Selametan Suran Di Desa Sutogaten
Kecamatan Pituruh Kabupaten Purworejo", Jurnal Program Studi Pendidikan Bahasa dan Sastra Jawa_Universitas Muhammadiyah Purworejo 2014.

Sunan Abu Dawud, no. 4607; Tirmidzi, 2676).

Sumber : Hasil Pengukuran SISMIOP Tahun 2004 Desa Alasbulu Kecamatan Wongsorejo Kabupaten Banyuwangi).

SutrisnoHadi, Metodologi Research, Jilid III ( Yogyakarta: Andi, 1999) h. 145. )

Spradley, J.P. 1997. Metode Etnogra fi. Terjemahan oleh Misbah Yulfa Elisabeth.Yogyakarta : PT Tiara Wacana Yogya.

Zulkarnain, "Tradisi Slametan Jumat Legi Upaya Mempertahankan Solidaritas Sosial Masyarakat Desa" , Jurusan Pendidikan Luar Sekolah FIP UM 2013. 